\title{
When bodies do not fit: an analysis of postgraduate fieldwork
}

Johanna Carolina Jokinen

Department of Social and Economic Geography - Uppsala University

Box 513, SE-751 20 Uppsala, Sweden

johanna.jokinen@kultgeog.uu.se

Dr. Martina Angela Caretta, $\mathrm{PhD} *$

Department of Geology and Geography - West Virginia University

98 Beechurst Ave

330 Brooks Hall, Office 349

Morgantown, WV 26506-6300

martina.caretta@mail.wvu.edu

This is an Accepted Manuscript of an article published by Taylor \& Francis Group in Gender,

Place \& Culture on 31/10/2016, available online:

http://www.tandfonline.com/doi/full/10.1080/0966369X.2016.1249343.

Word count: 7742

Cn: yes

Ackn: yes 


\title{
When bodies do not fit: an analysis of postgraduate fieldwork
}

\author{
Abstract \\ Feminist geographers are increasingly examining embodied aspects of research. These \\ embodied dimensions of fieldwork often build upon intersecting positionalities, yet studies \\ focusing on bodily limitations encountered by feminists in the field are relatively few. In \\ this article we explore what it is like to be bodies that do not fit easily into the context \\ within which they are supposed to be doing fieldwork. We are both female postgraduate \\ students conducting fieldwork in the Global South. We have encountered, many times \\ over, instances where, because of our sick and fatigued bodies, we have not been able to \\ continue our work. We question the normalization of able-bodied postgraduate students by \\ problematizing our own experiences, and argue that discourses of ability dominate \\ fieldwork, in both its expectations and its conduct. This is especially the case for those with \\ invisible disabilities because researchers may appear healthy but are not. As a result, \\ postgraduate students may jeopardize their health for the sake of their research.
}

Keywords: embodiment; fieldwork; PhD studies; invisible disability

\section{Introduction}

The study of geography is grounded in everyday experiences and phenomena which geographers investigate in their context: the field (see e.g. DeLyser and Starrs 2001; Moss 2005). As postgraduate students writing our dissertations in development geography, performing prolonged fieldwork in the Global South has been a fundamental part of our doctoral studies. When conducting ethnographic fieldwork, the field comprises all senses and bodily activities (GilliatRay 2010), which illustrates the argument that even field researchers understand places through their bodies (Nast 1998). Although the practice of 'being in the field' has profoundly changed since feminist geography's early days, many fieldwork activities such as walking and climbing are considered as excluding tasks requiring a fit and able body (Nairn 1999; Hall, Healey, and 
Harrison 2002). While the able-bodied requirements of field activities have been questioned in the literature on higher education pedagogy (Healey et al. 2002; Gilley et al. 2015), the fact that the researcher's sick and fatigued body represent a limiting factor of fieldwork also has been recognized by feminist geographers (Maguire 1998; Punch 2012).

Power and positionality are long-standing issues that feminist geographers have addressed in thinking about approaches to research, including fieldwork (Katz 1994; Kobayashi 1994; Billo and Hiemstra 2013). The significance of researcher's body as part of the field has been acknowledged by feminist geographers (Crang 2003; Sharp 2005). The use of the researcher's body as a research tool has also been brought up in discussions about how embodied reactions and differences between bodies can give new insights into research topics (Longhurst, Ho, and Johnston 2008).

The embodied dimensions of fieldwork are increasingly recognized by feminist scholars, often building upon on reflexivity at the intersection of race, gender, class, and age (e.g. Sundberg 2005; Hapke and Ayyankeril 2010). Researchers can be placed sometimes in vulnerable positions through their fieldwork because of their physical and emotional attributes. Gendered bodies can attract unwanted attention placing researchers in dangerous and violent situations (Malam 2004; Ross 2015). As well, emotional connections with communities, through for example marriage and family, can leave researchers exposed in their personal lives because of what they do in the field (Behar 2013; Smith 2014). Disabled bodies in the field are less talked about in the literature; however, ableism, that is, the oppression resulting from the ideal that everyone is able-bodied (Anderson 2001), has been problematized in relation to undergraduate students' capabilities to participate in field activities (Nairn 1999; Hall, Healey, and Harrison 2002; Hall and Healey 2005). Demands of fieldwork, in terms of the physicality of carrying out 
field tasks, have been discussed in terms of female bodies in physical geography (Bracken and Mawdsley 2004). This small body of literature encourages inclusive fieldwork preparation and practices, both in planning and in training, not the least of which because such diversity among bodies can enrich the discipline more generally (see also Healey et al. 2002; Gilley et al. 2015). Teasing out various aspects of embodied fieldwork can contribute to this debate. We frame our engagement with this work by asking: what happens when the postgraduate's body does not fit able-bodied norms? In our experiences of cross-cultural fieldwork comprising an array of embodied activities, our bodily limitations prompted us to devise strategies to withstand both the demands of the field and the conditions in which we found ourselves. We consciously improved our physical and emotional endurance. But when we could not, we reevaluated the viability of our fieldwork strategies in order to not give up on our research. Although disabling illnesses and conditions might steer the researcher's career path, disciplinary interests, and methodological choices (e.g. see Moss 1999, 2013), we could not immediately make this fundamental shift. Not only were we in the midst of a research project, but also, as postgraduates, we were required to complete the fieldwork and gather data for our dissertation.

Postgraduate fieldwork in geography is a true 'learning by doing' endeavor. Training in cross-cultural field research, often taking place far from one's support network, becomes even more challenging in the presence of bodily limitations. In this article, we discuss how we came to terms with what our bodies could not do through our lived experiences. Instead of being a resource in the research process (see Monaghan 2006), our bodies seemingly turned into a burden. As part of our argument, we interrogate the prevailing view of normality of able-bodied postgraduate students in human geography by arguing that training for fieldwork needs to be sensitive to bodily limitations in order to create awareness of potential challenges postgraduate 
students may face (Hansen and Philo 2007). These bodily limitations include both short-term and long-term conditions, as for example, pregnancy and life-limiting conditions.

We begin by presenting a set of grounding concepts for our analysis: embodiment, disabled bodies, and invisible disabilities and their relationships to fieldwork. We then recount and problematize several instances where our bodies did not fit in our field locations, which jeopardized our physical and emotional wellbeing. We discuss these instances in terms of shortterm and long-term invisible disabilities. We close with a short discussion about understanding fieldwork as embodied can assist in preparing for the field.

\section{Embodiment, disabled bodies and invisible disabilities in geographical fieldwork}

Embodiment, that is to say the role that the researcher's body plays in the research process, has been used by feminist geographers to challenge the idea that knowledge is neutral (e.g. Longhurst 2009; Ahmed 2004; Moss 2005). Through methodological reflexivity on embodiment and positionality in a research process, the researcher's embodied attributes can be used as a resource facilitating access to information when interfacing with participants if, for example, the researcher's embodiment resembles the participants' (Smith 2014) or do not otherwise pose a threat to the participants (Liong 2015). Feminist geographers have also shown how embodiment can be problematic and difficult to control, as the researcher's body can be a source of vulnerability in certain research situations, particularly when being considered as 'out of place' by participants (Parr 2001; Sharp 2005). Control of the researcher's bodily presence and the performed embodied activities are therefore central in fieldwork preparation (Monaghan 2006), as bodily reactions and emotions, including unwanted ones, is an integral part of the research process (Longhurst, Ho, and Johnston 2008). While the researcher's disability has been treated in the literature less often than other body signifiers, there is some discussion of such bodily 
difference. For instance, Ellingson (2006) notices that her visible disability affected how data were produced, by showing how her own identity as a researcher blurred through interaction with another patient while researching a healthcare provider. The ethics of disclosure is a topic of discussion, especially when the researchers' visible markers of disability can clearly affect how openly participants share information (Brown and Boardman 2011).

Disabled bodies are an effect of the social construction of disability as social oppression which varies depending on different spatio-temporal contexts (Gleeson 1996; Kitchin 1998). Disabilities are not the product of an impairment of a body part or bodily function (Stone 1995); rather, disability itself is located in societal barriers that limit access to activities. Disabilities can be temporally fixed, and depending on the circumstances, whether at home or in the office, or perhaps walking rather than sitting, can become more (or less) limiting (Peters 1993). Because of the prevailing system of ableism, people with bodily impairments, particularly minor ones, often try to hide their deviations by performing bodily activities as normally as possible (Hansen and Philo 2007). This urge to control one's body, or normalize it, is linked closely to a perceived fear of being disabled as a consequence of moral failure (Stone 1995; Wendell 1996). The attempt to pass as normal keeps disabled bodies out of sight, and consequently out of the field. But as Stone (1995) notes, there are no perfect bodies, every human body is occasionally impaired.

Invisible disabilities refer to disabled bodies that are not marked with disability through visual or aural clues. These conditions include the vast array of illness covering fluctuations in chronic pain, emotional distress, cognitive impairment, neurological impairment, and severe fatigue (e.g. Lightman et al. 2009; Davidson and Henderson 2010; Pilling 2013). Invisible disabilities have been also called hidden, episodic, and medium-term disabilities in relationship to the uneven manifestations of illness, some of which come under the wider umbrella term of 
contested illness (Moss and Teghtsoonian 2008). Inclusion of invisible disabilities in geography has mostly centered on teaching and training, rather than on dealing with invisible disabilities in undertaking research. For example, Matthews (2009) discusses how undergraduate students can be encouraged to disclose their invisible disabilities by creating inclusive learning environments that are open to diversity. To improve these students' learning experience, disability has to be included in the teachers' curriculum. We argue that such change will also have positive consequences for postgraduate candidates whose supervisors will be more aware of the possible hurdles that students with invisible disabilities face during fieldwork.

Disabled bodies in relation to the expectations of fieldwork have been mainly addressed through undergraduate students' participation in residential field trips. Maguire (1998) shows how female and mature students more often describe themselves as having inadequate fitness level for fieldwork activities. Nairn (1999) considers in more general terms how typical fieldwork activities of walking and climbing limits the participation of students having invisible disabilities, for instance asthma and lack of physical fitness. Hall, Healey and Harrison (2002) explore how disabled students, including visible disabilities such as mobility and visual impairment, are in various ways excluded in geographical fieldwork. These works taken together examine ableism in undergraduate field trips and provide advice on how to design more accessible field courses by balancing between politics of inclusion and the requirements of academic rigor (see also Healey et al. 2002; Gilley et al. 2015).

In this article, we suggest that postgraduate training should explicitly take up a discussion of disabling bodily conditions that are not visible for these may be a limiting factor in undertaking geographical field research. Because such conditions might only appear in certain contexts, fieldwork in remote and unfamiliar locations can be a triggering and worsening factor 
of disability. Owing to ableism, visible disabilities are more easily points of discussion with colleagues and supervisors than disabling bodily conditions that must be disclosed. Reliance on visual clues to bring disability into the training of postgraduate students leads to the normalization of postgraduates as able-bodied, leaving doctoral students with invisible disabilities trying to live up to ableist expectations, which might jeopardize their physical and mental health when performing research activities that do not fit their bodies.

It is within this context that we discuss our own fieldwork experiences as postgraduate students with invisible disabilities. We show in the next sections that it was challenging for us to carry out several of the everyday tasks in the field, such as walking, climbing, and eating, because of our bodily limitations. We treat these embodied conditions as both short-term and long-term invisible disabilities, including lack of physical fitness, bacterial infections, severe allergies, and asthma. We also discuss how we tried to adjust our bodies to conduct field activities according to the able-bodied standards. Through these experiences, we learned to create our own strategies on how to complete geographical fieldwork in challenging environments while being conscious of our bodily limitations.

\section{Short-term invisible disabilities}

In this section we present two examples of short-term invisible disabilities that Martina experienced during her fieldwork. First, she thought she lacked physical fitness to be able to successfully accomplish her dissertational fieldwork. So she began a fitness regimen in an attempt to resemble the ideal geographer's body. Second, in order not to appear weak in front of her geographer colleagues, she did not disclose the gravity of the stomach virus she acquired during fieldwork, which lasted well after her return from the field and resulted in a long-term invisible disability. 


\section{Lack of fitness: the shifting nature of embodiment}

Martina's research focuses on small holder irrigation farming practices and women's participation in irrigation management in East Africa (Caretta, 2015a). After her first fieldwork in 2011, Martina realized that her body size was a burden for her research. Not only was the heat in the dry-lands of East Africa unbearable, but there was an undeniable difficulty in trekking to visit participants and carrying out interviews while walking up steep hills along irrigation canals. Once while jumping across a canal, she said to her supervisors who were on a field visit: 'You should have mentioned trekking in the range of skills that you expected the candidate to have!' The expectation that a postgraduate would be able to conduct this type of physically demanding fieldwork was taken to be self-evident and not in need of discussion.

As both Nairn (1999) and Maguire (1998) report in their studies of female students' accounts of fieldwork, Martina realized that she was lacking the physical fitness that would ensure the completion of fieldwork and, eventually, of her doctoral degree. While her friends and colleagues had never talked to her about body size being a limitation, she decided on her own to lose weight through a controlled eating and exercise regimen. She did resistance training and lost considerable weight so that her return to the second season of fieldwork would be less physically demanding.

Martina's actions were problematic. Even though she was more fit and felt better while in the field, she contributed to reproducing the ableist premises about fieldwork that marginalized her during her training and first season of fieldwork. By losing weight Martina distanced herself from the ideal of an African woman's body which triggered unexpected reactions in participants to her study. Fatness is in fact socially accepted and actually seen as a sign of good health among participants of her study in Kenya and Tanzania. Upon her return in 2013, 14 kilograms smaller, 
most of people were worried because they thought she had been sick since they perceived that weight loss was a result of faltering health. Martina did not want her weight loss to be a statement of alignment to the Western representations of ideal female slim bodies (see also Longhurst 2012), but she had not expected that it would trigger such preoccupation among research participants.

Martina's diary, 1 February 2013: Yesterday when my assistants saw me after 7 months the first thing they asked me was 'Are you sick? You must eat more'. I had not expected this reaction. This morning when we walked around the village, people I had interviewed before claimed they couldn't even recognize me because of my changed look. When they understood it was me they said 'We are sorry to see that you have had health issues'. It is frustrating. I made such an effort to make my fieldwork easier by dieting and now I am questioned for it and it sounds like I made a mistake. ${ }^{1}$

This episode shows 'the shifting and temporal nature of embodiment' (Longhurst 2012, 872). While Martina's body size was never a topic of interest early on in the research, it later became out of place as her weight loss had destabilized the bodily identity that participants had attached to her (after Parr 2001). It was difficult for interviewees to understand that Martina had reduced her weight voluntarily. Her condition triggered discussions with participants during her last fieldwork about health and canons of beauty in Sweden, Kenya, and Tanzania.

Referring to Martina's size, men would say: 'We like our women fat, so they are strong and can have many children. 'You won't be able to have children if you are that skinny.' (Martina's notes July 2013). This statement not only mirrors the normative character of accepted bodily appearance, but it is an expression of the local traditional patriarchal power relations. Women are seen primarily as mothers, and their value is defined according to masculine preferences. She was questioned as a woman in her childbearing age whose body did not fit into 
the local canons and was not apt for procreation. There is no doubt that these comments had an emotional impact on Martina. They impinged on her intimacy and privacy much like study participants in Ladakh, India, did with Smith (2014) when questioning her about her marriage with a local. Martina had no desire of having children at the time, yet she experienced mixed feelings hearing those words. It first felt offensive. While she felt sad and angry about the infringement, she did not react to this statement in the moment because she did not want to confront participants or sound unpleasant to those people with which she had to keep working. The need to continue her research, without dwelling on emotional matters that would derail interviews, overrode her own feelings. As an outlet, when walking from one interview to other, Martina would vent with research assistants about how it felt to be the target of such intrusive comments. Research assistants helped her understand participants' talk about her own body so that they did not read her reactions incorrectly (for further analysis see Caretta, 2015b). Intimacy and friendship with participants and assistants, an element that is seldom dwelled upon in the literature (e.g. Smith 2014), shows that fieldwork is and cannot be solely about data collection. Stomach virus: acute condition transformed into long-term disability

Bacterial infections, yellow fever, and malaria can all be prevented by using precautions through vaccinating, packing medicine, and preparing for common illnesses. Access to health facilities varied and was completely out of reach for Martina in some places. She was careful about the food she ate and the water she drank making sure everything had been thoroughly cooked and boiled. Yet, when Martina carried out interviews at participants' places they were always adamant she took chai (milk tea typical of Kenya and Tanzania). Offering her drinks and food was the highest sign of hospitality and she was thankful for participants' gesture in sharing 
their limited resources with her. She drank her chai even though she knew it posed risks for a bacterial infection (see also Punch 2012; Billo and Hiemstra 2013).

In one of these settings, Martina ate a chapatti (flat bread) made out of flour, which had been transported side by side with gasoline. During the bumpy ride, gasoline spilled over and got absorbed by the flour, which had been dried and sold anyway. The chapatti was contaminated and Martina got poisoned. Vomit and diarrhea made work impossible for several days. Having no access to any doctor, Martina used the medicines she had taken with her and kept herself hydrated with bottled water she had bought in Nairobi before taking off to the field. She was discouraged and depressed, being bed-bound in the heat with limited access to running water. She knew that her body would have bounced back more quickly at the beginning of fieldwork, but after one month of a limited diet, vitamin supplements were not sufficient anymore (see also Leslie and Storey 2003; Punch 2012). She constantly felt weak and lightheaded and rarely slept through the night. When, some weeks after, she was in Tanzania, concluding her seven weeks of fieldwork, she suffered again from the same symptoms, which she surmised to be linked to unclean water and fresh milk mixed in chai. She was time-pressed, had no access to any sort of telecommunication, and, because the driver had agreed to pick her up one week later, she decided to keep on working long days even though she could hardly focus on the tasks at hand. When she returned to Sweden her health did not improve: she did not disclose her condition to her supervisors because she did not want to appear weak and she did not want to create the impression that she had somehow failed.

Martina's diary, 10 September 2014: I have been back from Tanzania now for 6 weeks and I have not been able to keep down a meal for more than 3 hours. I feel like my brain is also getting drained down the toilet. I can hardly focus and work. At times I am getting so dehydrated that I feel like fainting. 
She kept on teaching and working on her thesis. She did not eat before lectures or meetings in order to keep feelings of sickness at bay. Her life quality was seriously impaired for several months during which fatigue and light fevers would present themselves regularly. She was never referred to a tropical infections specialist and it took more than seven months to start recovering from several bacteria that had been harboring in her intestines. This prolonged, weakened state of health was disheartening. She was eventually diagnosed with celiac disease.

Martina's diary, 15 October 2013: I am so relieved this was my last fieldwork. I have been diagnosed with several bacterial infections and I have lost part of my intestinal wall. I won't be able to do fieldwork again, at least for a prolonged period. I am now terrorized about going back to the field again, plus I can hardly focus on my work for more than 4 hours due to constant intestinal pains. I wonder whether my chance of being a 'real' geographer has been put into jeopardy.

What began as a temporary sickness, which she hid during and after fieldwork so as not to be doubted as a virtuous member of her discipline, turned into a lifelong condition that will shape her career choices as a geographer.

\section{Long-term invisible disabilities}

In this section, we report on two examples of long-term invisible disabilities that troubled Johanna during her fieldwork. First, when planning her fieldwork, she had already realized that her food allergy was potentially a life-threatening condition that would determine the spatiotemporal context of her data collection. While she always had these allergies and asthma, she had never experienced them as disabling factors when conducting several pre-doctoral field studies in remote locations of the Global South. Second, she was suffering from fatigue during her first fieldwork in an attempt to adjust to non-disabled practices without acknowledging her asthma as 
a disability.

\section{Severe allergies: life-threatening condition steering research choices}

Johanna's research focuses on transnational labor migration and its impact on agricultural land use and livelihood strategies in Bolivian peri-urban and rural out-migration villages. Only four months prior to leaving for her first fieldwork in Bolivia in 2013, Johanna was informed by her physician that she could not take the yellow fever vaccine due to her egg allergy. Although she had been aware of the health risks associated with the vaccine, she had repeatedly looked into the possibility of getting immunized anyway. The irrevocable decision not to be vaccinated led to discussions with her supervisors on the appropriateness of conducting research in Bolivia. Because Johanna felt responsible to keep her commitment with the Bolivian research center where she had undertaken a pre-doctoral field visit in 2011, she went ahead with her planned study and tried to select case study sites that were located at a minimum altitude of 2,300 meters so as to avoid mosquito bites. Even with such clear precautions in place, she still had to negotiate her commitments to the research project because several lowland locations turned out to be relevant to her study. For instance, Johanna was invited for a short visit to conduct interviews in a nearby lowland region where some of her participants had bought agricultural land with their migrant remittances. Although tempted, she remembered how anxious she was when she developed a high fever after being bit my mosquitoes during her visit in the lowland city of Santa Cruz de la Sierra. As the following email demonstrates, she eventually understood that it would be unnecessary and irresponsible of her to risk contracting yellow fever.

Johanna's email to her supervisor, 27 October 2014: I read about a man from Potosi who had traveled [to the lowland region] without vaccinating himself a few years ago, and he was infected by yellow fever and died. It is not such a high risk but at the same time, it would be 
horrible if it happens. I also read that there are sometimes road checkpoints and if you are not vaccinated, you will be given the vaccine there. I have a certificate of my allergy but I don't know if it would be respected, and it isn't anything I would like to expose myself to.

As the email indicates, it was not easy for Johanna to admit that her invisible disability was limiting her physical and mental ability to perform geographic fieldwork. It was also difficult for her to accept that her bodily impairment could not be fixed through vaccination (see also Stone 1995). As Moss (2013) describes how her academic interests were influenced by her chronic illness, Johanna was feeling that she had made a wrong career choice by focusing on development geography and tropical land use because her disability would limit her chances to work in large parts of the Global South. While her supervisors were ready to discuss alternative fieldwork settings for her doctoral research, Johanna herself did not want to abandon the study that she had been planning for over two years. Pursuing to keep her research plan intact, Johanna was accepting and reproducing the able-bodied norms of postgraduate fieldwork (see also Kitchin 1998).

Although Johanna tried to be extremely careful about her eating behavior because of her wheat allergy, her field visits and interviewing were interrupted twice owing to a severe allergic reaction. First, she and her assistants had lunch with community members. The decision to eat that particular lunch was not only about pleasing their hosts by accepting their warm hospitality, but also to save time because they would have had to travel to the closest city and back before being able to continue with interviews. An apparently simple meal consisting of rice, chicken, tomato sauce, and salad caused a sudden, dangerous allergic reaction. Second, she suffered from an even more serious allergic incident after drinking chicha, a fermented maize beverage offered to her by her field assistants. She gulped down only a little to please her assistants' continuous requests to taste chicha, without thinking that it might contain malt. When conducting an 
interview half an hour later, Johanna detected hives on her arms and eyelid swelling. Because it was her final field visit to the most remote study location and had been difficult to recruit informants, she chose not to interrupt the interview. She tried to complete the interview quickly knowing that she was suffering from signs of anaphylaxis. Immediately after finishing the interview, she used her epinephrine auto-injector and received additional treatment shortly thereafter at a small rural health clinic.

Johanna's email to her family member, 20 January 2014: I had to lie on a bare examination table, and they put a dirty cloth on my stomach. Then I was given an intravenous injection in my arm. It seemed they took a new needle and the arm was first disinfected with alcohol. But I was still quite terrified.

Johanna felt remorse about using the rural health facility's limited resources as a visiting researcher. Due to the graveness of anaphylactic shock, in the moment, she criticized the health care center conditions from a Eurocentric perspective wanting clean examination tables, cloths, and IV needles. Comparable to bodily reactions of disgust to unfamiliar savors (Longhurst, Ho, and Johnston 2008), Johanna's emotional reaction of discomfort and fear turned her body into a research instrument, enhancing her awareness of how her positionality and immediate reactions might hamper her relations with research participants (Ahmed 2004). This example also demonstrates how a researcher's body becomes an uncontrollable tool owing to disabling conditions, as Johanna experienced that her body was threatened by the rustic clinic conditions (see also Parr 2001).

These instances reveal how the field can become a potentially hazardous place for Johanna because of her invisible, life-threatening disabilities. As a precaution, she decided to only conduct research in peri-urban sites located close to a major city so as to be closer to better healthcare facilities. She also began to carry her own food with her and to refuse when offered 
chicha by her participants. In this way, Johanna balanced her commitment to reducing research power hierarchies (Malam 2004) by having, for instance, a drink together with one's participants (Parr 2001), her dedication to collecting good quality data, and her promise to protecting her own health (see also Punch 2012; Ross 2015).

\section{Asthma: when a 'harmless' condition becomes hazardous in unfamiliar environment}

During the last month of her first fieldwork, Johanna was aware of limited time she had and decided to conduct interviews during as many field visits as possible, even every weekend, without caring of her need to rest. She was also troubled by asthma due to a combination of high altitude, semi-arid climatic conditions, and an excessive amount of airborne dust and contamination.

Johanna experienced exhaustion caused by too little sleep and stress in trying to combine field visits with her commitment to participate in seminars and give a GIS course at the local research center. Because her interviewing had been hampered by allergic reactions and because she also had to cancel field trips due to protest-caused roadblocks, Johanna was increasingly worried of not being able to complete her fieldwork during the days she had left in the field. Even though exhausted, she was cramming visits into her schedule, and finding it difficult to keep up with them. When her assistant reported being too busy to help with the final set of interviews, Johanna could no longer control her emotions and frustration, and lashed out at her assistant.

Johanna's sms to her assistant, 20 January 2014: So there is no other assistant who could help me today [instead of you]? I already came to the research center without my laptop and it is just waste of time for me to go back home now without even being able to stay working at the University. If you only had told me yesterday that you cannot go with me [to the field], I could have been able to find another assistant. 
Feeling defeated through frustration and exhaustion, Johanna started to cry. When walking back to her apartment, she accidentally fell down when crossing a street.

Johanna's sms to her family member, 20 January 2014: I fell down earlier today but have been then running around and taking care of different things all the day, and now I just noticed that my big toe is completely black and swollen. I even ripped the knees of my trousers. I will go to bed now so I will hopefully be more vigilant tomorrow. I think I fell down inadvertently just because of this tiredness.

Johanna experienced sudden mood changes, irritability, crying, and lack of mindfulness towards other. This condition is commonly defined as fatigue: a state of tiredness caused by both emotional and physical distress which can stem from logistical challenges, illness, and security concerns among other things (Heller et al. 2011; Moss 2001). Johanna's example shows how her asthma, that usually was asymptomatic and thus rather harmless, became hazardous in the biophysical environment of high altitude and semi-arid climate (see also Peters 1993; Moss 2005). Given that she had never before had difficulties in participating in geographical excursions in challenging terrain, she had not even thought about the possibility that the unfamiliar environmental conditions together with her illness could pose a threat to her research (see also Hall and Healey 2005). As she did not want to recognize her disability as a limitation, she continued with the nearly daily field visits to keep up with the ableist expectations of data collection (Stone 1995; Hansen and Philo 2007), without taking seriously her state of exhaustion. Given the incidents that took place during her first visit to Bolivia, in order to control onset of asthma and exhaustion, Johanna needed to make adjustments to her asthma medications and strive for only being in the field during the rainy season when there are less dust particles in the air (cf. Punch 2012). During the second visit, she planned for an actually breaks in data collection. As other postgraduates have created field strategies to protect themselves against 
gendered risks (Malam 2004; Ross 2015) and angry dogs (Punch 2012), Johanna came up with strategies to continue with the fieldwork despite her disabled body. In retrospect, based on all the physical challenges she faced, Johanna now thinks that her choice of Bolivia was not a fully informed one. Had she fully understood the implications of her disability, she would have conducted her empirical study in a field location that would have been fit for her body.

\section{Conclusion}

Following Ahmed (2004), when reflecting on our emotions and how they drove our research process during our fieldwork, we can show that 'knowledge cannot be separated from the bodily world' (171). Yet we still must plan even though it is not easy to anticipate possible bodily restrictions when writing a research proposal as a new $\mathrm{PhD}$ student. Invisible bodily conditions that can be harmless in familiar contexts, can become disabling and even life-threatening in fieldwork settings. Therefore, in addition to temporal and subjective variation (Longhurst 2012), we argue that embodiment also involves a clear place-bound component. In Martina's case, Kenya and Tanzania were not only two educational sites where she had overcome challenges, had gotten to know friendly people and had carried out inspiring and enriching investigation: they became the places where she experienced the limitations of her body and where she was forced to question her capability of being a strong, able-bodied geographer (see also Nairn 1999). In Johanna's case, she became surprised at the bodily challenges she faced based on the environmental, cultural, and socio-economic conditions in Bolivia. While she remembered her first fieldwork season as a time of exhaustion and of being far away from support networks, her second fieldwork season was more successful owing to the acknowledgment of her bodily limitations (see also Stone 1995) and the implementation of a set of carefully laid out precautionary measures (see also Malam 2004; Punch 2012; Ross 2015). Despite the previous 
embodied difficulties, she is at present looking forward to her next, and last, prolonged fieldwork in Bolivia.

We maintain that our physical capacity to conduct active fieldwork in demanding conditions was never brought up as a topic for discussion during our postgraduate programs because of the prevailing masculinist understanding of geographers being able-bodied. While there have been professional development seminars and doctoral courses on field research included in our training, the embodied dimension of bodily limitations in the field, including potential health problems, was not explored in those forums because of the disembodied ideal of the geographer's able body. As a consequence, we did not consider our invisible disabilities when reflecting on embodiment and positionalities in cross-cultural research during our prefieldwork training.

Once we noticed our limitations due to lacking physical fitness, inadequate bacterial flora, food allergy, asthma, and fear of becoming sick, we tried to make our bodies fit into the field by losing weight and on medication. While we went through the geographers' rite of passage proving that we are able to carry out fieldwork in the Global South, our field practices were admittedly troubled by unexpected bodily dilemmas. We have argued that the idealization of a geographer's body in effect normalizes all bodies as machine-like entities that are expected to participate in any kind of field activities. Flexibility in field research could be enhanced simply be discussing how bodies fit into research processes, thus increasing 'the normality of doing things differently' (cf. Hansen and Philo 2007, 493).

Along with Matthew (2009), we hold that a discussion of the implications for researchers having visible and invisible disabilities needs to be included in research training much like gendered, sexualized, and racialized positionalities. Including disability promotes a working 
environment that is even more open to diversity where postgraduate students will feel at ease discussing their invisible disabilities and planning realistically attainable fieldwork. In this article, we draw attention to how the lack of any acknowledgment of potential invisible disabilities meant that we set unattainably high expectations and unrealistic ambitions without taking into account our own bodily limitations, which led to stress, frustration, and fatigue in the field. Having to fine-tune our physical and emotional endurance was a demanding process that we have been able to turn into a learning opportunity. We wish to share our lessons of not fitting in with our fellow postgraduates as a way to include disabilities, especially invisible ones, to the discussion around embodied dimensions of fieldwork alongside other bodily differences.

\section{Notes}

${ }^{1}$ Autobiographical material presented here was written by the authors in English, Swedish, Italian, Swahili, Finnish, and Spanish, and was all translated by the authors themselves into English.

\section{Acknowledgements}

Jokinen's field study was carried out thanks to the financial support of the Swedish Society for Anthropology and Geography, Helge Ax:son Johnson's Foundation, and Håkansson’s travel grant, Uppsala University. Caretta's field study (research authorizations: TZ: PF/IRA.15; KE: NCST/RDC/10/013/16) was carried out thanks to the financial support of the Swedish International Cooperation Agency (SWE2009-210). Thanks to three anonymous reviewers, to Taylor Brydges for language proofing an earlier version of the manuscript, and especially to Pamela Moss for the support and guidance in getting this article published.

\section{Notes on contributors}

Johanna Carolina Jokinen is a doctoral student at the Department of Social and Economic Geography at Uppsala University. Her doctoral dissertation investigates transnational labor migration and its impacts on rural livelihoods and agricultural land use in out-migration communities in Bolivia. She teaches GIS, remote sensing, cartography and geopolitics in BA 
courses. She holds a MSc in Geography and a BA in Latin American Studies from Stockholm University, Sweden.

Martina Angela Caretta is an Assistant Professor at the Department of Geology and Geography at West Virginia University. She holds a PhD in Geography Stockholm University. She is a feminist geographer investigating the human dimensions of water in the global south. Her doctoral dissertation investigated gender contracts in small holder irrigation farming systems in Kenya and Tanzania. Her work has been published in The Geographical Journal, in Climate \& Development and in Qualitative Research, among other journals.

\section{References}

Ahmed, Sara. 2004. The Cultural Politics of Emotion. Edinburgh: Edinburgh University Press.

Anderson, Carolyn Anne. 2001. "Claiming disability in the field of geography: access, recognition and integration." Social \& Cultural Geography 2 (1): 87-93. doi:10.1080/14649360020028294.

Behar, Ruth. 2013. Traveling Heavy: A Memoir in between Journeys. Durham: Duke University Press.

Billo, Emily, and Nancy Hiemstra. 2013. "Mediating messiness: expanding ideas of flexibility, reflexivity, and embodiment in fieldwork." Gender, Place \& Culture: A Journal of Feminist Geography 20 (3): 313-328. doi:10.1080/0966369X.2012.674929.

Bracken, Louise (née Bull), and Emma Mawdsley. 2004. “"Muddy glee’: rounding out the picture of women and physical geography fieldwork." Area 36 (3): 280-286. doi:10.1111/j.0004-0894.2004.00225.x.

Brown, Lindsey, and Felicity K. Boardman. 2011. "Accessing the field: Disability and the research process." Social Science \& Medicine 72 (1): 23-30.

doi:10.1016/j.socscimed.2010.09.050.

Caretta, Martina Angela. 2015a. East African Hydropatriarchies: An analysis of changing waterscapes in smallholder irrigation farming. Stockholm University, Faculty of Social Sciences, Department of Human Geography. ISBN: 978-91-7649-206-2. diva2:853702

Caretta, Martina Angela. 2015b. Situated knowledge in cross-cultural, cross-language research: a collaborative reflexive analysis of researcher, assistant and participant subjectivities. Qualitative Research 4, 489-505. doi: 10.1177/1468794114543404 
Crang, Mike. 2003. “Qualitative methods: touchy, feely, look-see?” Progress in Human Geography 27 (4): 494-504. doi:10.1191/0309132503ph445pr.

Davidson, Joyce, and Victoria L. Henderson. 2010. "“Coming out' on the spectrum: autism, identity and disclosure." Social \& Cultural Geography 11 (2): 155-170. doi:10.1080/14649360903525240.

DeLyser, D. and Starrs, P. F. 2001. “Doing Fieldwork: Editors' Introduction.” Geographical Review 91 (1-2): iv-viii. http://www.jstor.org/stable/3250797.

Ellingson, Laura L. 2006. “Embodied Knowledge: Writing Researchers’ Bodies Into Qualitative Health Research." Qualitative Health Research 16 (2): 298-310. doi:10.1177/1049732305281944.

Gilley, Brett, Chris Atchison, Anthony Feig, and Alison Stokes. 2015. "Impact of inclusive field trips.” Nature Geoscience 8: 579-580. doi:10.1038/ngeo2500.

Gilliat-Ray, Sophie. 2010. "Body-works and fieldwork: Research with British Muslim chaplains." Culture and Religion: An Interdisciplinary Journal 11 (4): 413-432. doi:10.1080/14755610.2010.527615.

Gleeson, B. J. 1996. “A geography for disabled people?” Transactions of the Institute of British Geographers 21 (2): 387-396. doi:10.2307/622488.

Hall, Tim, Mick Healey, and Margaret Harrison. 2002. "Fieldwork and disabled students: discourses of exclusion and inclusion." Transactions of the Institute of British Geographers 27 (2): 213-231. doi:10.1111/1475-5661.00050.

Hall, Tim, and Mick Healey. 2005. “Disabled students' experiences of fieldwork.” Area 37 (4): 446-449. doi:10.1111/j.1475-4762.2005.00649.x.

Hansen, Nancy, and Chris Philo. 2007. "The Normality of Doing Things Differently: Bodies, Spaces and Disability.” Tijdschrift voor economische en sociale geografie 98 (4): 493506. doi:10.1111/j.1467-9663.2007.00417.x.

Hapke, H. M. and Ayyankeril, Devan. 2010. "Of "Loose” Women and "Guides," or, Relationships in the Field." 91 (1-2): 342-352. doi:10.2307/3250836.

Healey, Mick, Carolyn Roberts, Alan Jenkins, and Jonathan Leach. 2002. "Disabled Students and Fieldwork: Towards Inclusivity?” Planet 5: 9-10. doi:10.11120/plan.2002.00050009.

Heller, Elizabeth, Julia Christensen, Lindsay Long, Catrina A. Mackenzie, Philip M. Osano, Britta Ricker, Emily Kagan, and Sarah Turner. 2011. "Dear Diary: Early Career 
Geographers Collectively Reflect on Their Qualitative Field Research Experiences." Journal of Geography in Higher Education 35 (1): 67-83. doi:10.1080/03098265.2010.486853.

Katz, Cindi. 1994. "Playing the Field: Questions of Fieldwork in Geography." The Professional Geographer 46 (1): 67-72. doi:10.1111/j.0033-0124.1994.00067.x.

Kobayashi, Audrey. 1994. Coloring the Field: Gender, "Race," and the Politics of Fieldwork. The Professional Geographer 46 (1): 73-80. doi:10.1111/j.0033-0124.1994.00073.x.

Kitchin, Rob. 1998. “'Out of Place', 'Knowing One's Place': space, power and the exclusion of disabled people." Disability \& Society 13 (3): 343-356. doi:10.1080/09687599826678.

Leslie, Helen, and Donovan Storey. 2003. "Practical Issues." In Development Fieldwork: A Practical Guide, edited by Regina Scheyvens and Donovan Storey, 77-95. London: Sage Publications.

Lightman, Ernie, Andrea Vick, Dean Herd, and Andrew Mitchell. 2009. "Not disabled enough': Episodic disabilities and the Ontario Disability Support Program." Disability Studies Quarterly 29 (3). http://dsq-sds.org/article/view/932/1108.

Liong, Mario. 2015. "Like father, like son: negotiation of masculinity in the ethnographic context in Hong Kong." Gender, Place \& Culture: A Journal of Feminist Geography 22 (7):937-953. doi:10.1080/0966369X.2014.917280.

Longhurst, R. 2009. "Embodied Knowing." In International Encyclopedia of Human Geography, edited by Rob Kitchin and Nigel Thrift, 429-433. Oxford: Elsevier Science.

Longhurst, Robyn. 2012. "Becoming Smaller: Autobiographical Spaces of Weight Loss." Antipode 44 (3): 871-888. doi:10.1111/j.1467-8330.2011.00895.x.

Longhurst, Robyn, Elsie Ho, and Lynda Johnston. 2008. "Using 'the body' as an 'instrument of research': kimch'i and pavlova." Area 40 (2): 208-217. doi:10.1111/j.14754762.2008.00805.x.

Maguire, Sarah. 1998. "Gender differences in attitudes to undergraduate fieldwork." Area 30 (3): 207-214. http://www.jstor.org/stable/20003897.

Malam, Linda. 2004. Embodiment and Sexuality in Cross-cultural Research. Australian Geographer 35 (2): 177-183. doi:10.1080/0004918042000249485. 
Matthews, Nicole. 2009: “Teaching the 'invisible' disabled students in the classroom: disclosure, inclusion and the social model of disability." Teaching in Higher Education 14 (3): 229239. doi:10.1080/13562510902898809.

Monaghan, Lee F. 2006. "Fieldwork and the Body: Reflections on an Embodied Ethnography." In The SAGE Handbook of Fieldwork, edited by Dick Hobbs and Richard Wright, 225241. London: SAGE Publications.

Moss, Pamela. 1999. “Autobiographical Notes on Chronic Illness.” In Mind and Body Spaces: Geographies of Disability, Illness and Impairment, edited by Ruth Butler and Hester Parr, 155-166. London: Routledge.

Moss, Pamela. 2001. “Writing One's Life.” In Placing autobiography in geography, edited by Pamela Moss, 1-21. Syracuse: Syracuse University Press.

Moss, Pamela. 2005. “A Bodily Notion of Research: Power, Difference, and Specificity in Feminist Methodology.” In A Companion to Feminist Geography, edited by Lisa Nelson and Joni Seager, 41-59. Malden, MA: Blackwell Publishing.

Moss, Pamela. 2013. "Becoming-undisciplined through my Foray into Disability Studies." Disability Studies Quarterly 33 (2). http://dsq-sds.org/article/view/3712/3232.

Moss, Pamela, and Katherine Teghtsoonian. 2008. Contesting Illness: Processes and Practices. Toronto: University of Toronto Press.

Nairn, Karen. 1999. “Embodied Fieldwork.” Journal of Geography 98 (6): 272-282. doi:10.1080/00221349908978941.

Nast, Heidi J. 1998. "The body as "place": Reflexivity and fieldwork in Kano, Nigeria.” In Places through the body, edited by Heidi J. Nast and Steve Pile, 93-116. London: Routledge.

Parr, Hester. 2001. "Feeling, Reading, and Making Bodies in Space." The Geographical Review 91 (1-2): 158-167. doi:10.1111/j.1931-0846.2001.tb00469.x.

Peters, Sherry L. 1993. “Having A Disability 'Sometimes'.” Canadian Women Studies 13 (4): 26-27. http://cws.journals.yorku.ca/index.php/cws/article/viewFile/10276/9365.

Pilling, Merrick Daniel. 2013. "Invisible Identity in the Workplace: Intersectional Madness and Processes of Disclosure at Work.” Disability Studies Quarterly 33 (1). http://dsqsds.org/article/view/3424/3204. 
Punch, Samantha. 2012. "Hidden struggles of fieldwork: Exploring the role and use of field diaries.” Emotion, Space and Society 5 (2): 86-93. doi:10.1016/j.emospa.2010.09.005.

Ross, Karen. 2015. "“No Sir, She Was Not a Fool in the Field”: Gendered Risks and Sexual Violence in Immersed Cross-Cultural Fieldwork." The Professional Geographer 67 (2): 180-186. doi:10.1080/00330124.2014.907705.

Sharp, Joanne. 2005. "Geography and gender: feminist methodologies in collaboration and in the field." Progress in Human Geography 29 (3): 304-309. doi:10.1191/0309132505ph550pr.

Smith, Sara. 2014. "Intimacy and angst in the field." Gender, Place \& Culture: A Journal of Feminist Geography. Advance online publication. doi:10.1080/0966369X.2014.958067. http://cws.journals.yorku.ca/index.php/cws/article/viewFile/10269/9358.

Stone, Sharon Dale. 1995. "The Myth of Bodily Perfection.” Disability \& Society 10 (4): 413 424. doi:10.1080/09687599550023426.

Sundberg, Juanita. 2005. "Looking for the critical geographer, or why bodies and geographies matter to the emergence of critical geographies of Latin America." Geoforum 36 (1): 17 28. doi:10.1016/j.geoforum.2004.03.006.

Wendell, Susan. 1996. The Rejected Body: Feminist Philosophical Reflections on Disability. New York: Routledge. 